\title{
Why biomanipulation can be effective in peaty lakes
}

\author{
Gerard ter Heerdt • Michiel Hootsmans
}

(C) Springer Science+Business Media B.V. 2007

\begin{abstract}
The effects of fish stock reduction (biomanipulation) was studied in an 85 ha shallow peaty turbid lake. The lake cleared in a 4week period in April-May 2004, which demonstrated that biomanipulation can be effective in peaty lakes. We demonstrated that it is possible to reduce the fish stock to $<25 \mathrm{~kg} \mathrm{ha}^{-1}$ benthivorous fish and $<15 \mathrm{~kg} \mathrm{ha}^{-1}$ planktivorous fish, sufficiently low to switch the lake from a turbid to a clear state. Knowledge of lake morphology, fish stock, fish behaviour, and a variety of fishing methods was necessary to achieve this goal. It is expected that continuation of fisheries to remove young of the year planktivorous species is needed for several years, until macrophytes provide sufficient cover for zooplankton and can compete with phytoplankton. Cladocerans developed strongly after fish removal. The clearing of the lake coincided with a sudden decrease of filamentous cyanobacteria and suspended detritus, and a strong increase of Bosmina. We assume that
\end{abstract}

Guest editors: R. D. Gulati, E. Lammens, N. De Pauw \& E. Van Donk

Shallow lakes in a changing world

G. ter Heerdt $(\bowtie) \cdot$ M. Hootsmans

Waternet, Post Box 8169, 1005 AD Amsterdam,

The Netherlands

e-mail: gerard.ter.heerdt@waternet.nl

M. Hootsmans

e-mail: michiel.hootsmans@waternet.nl
Bosmina was able to reduce filamentous prokaryotes and detritus. After the disappearance of the cyanobacteria, Bosmina disappeared too. After the clearing of the lake Daphnia dominated in zooplankton and apparently was able to keep phytoplankton levels low. In our case, wind resuspension did not prevent biomanipulation from being successful. No correlation between windspeed and turbidity was found, neither in an 85 ha nor in a 230 ha shallow peaty lake. Regression analysis showed that on average $50 \%$ of the amount of suspended detritus can be explained by resuspension by fish and $50 \%$ by phytoplankton decomposition. The main goal of this biomanipulation experiment, clear water and increased submerged plant cover in a shallow peaty lake, was reached.

Keywords Biomanipulation · Peaty lakes · Phytoplankton · Zooplankton · Fish · Wind · Resuspension · Detritus · Macrophytes

\section{Introduction}

Fish stock reduction, or 'biomanipulation', can switch a turbid lake to a clear state, provided that nutrient levels are not too high (Jeppesen et al. 1990a, 1990b, 1997; Meijer et al., 1994, 1999; Perrow et al., 1997; Scheffer, 2001; Gulati \& Van Donk, 2002). By reducing benthivorous fish, such 
as bream (Abramis brama L.), sediment resuspension is reduced. Reducing planktivorous fish, such as roach (Rutilus rutilus L.) and small bream, reduces predation pressure on zooplankton, leading to top-down control of phytoplankton. The reduction of suspended solids and algae will increase water clarity and promotes increase of submerged aquatic plants that help maintaining the new phase (Jeppesen et al., 1997; Scheffer, 2001; Gulati \& Van Donk, 2002).

However, compared with results in mineral bottom lakes, biomanipulation in peaty lakes in the Netherlands has not been successful (Van Liere \& Gulati, 1992; Meijer et al., 1999; Gulati \& Van Donk, 2002). In this paper we will discuss the possible reasons for this failure, illustrated with a whole lake biomanipulation experiment in the shallow peaty Lake Terra Nova in The Netherlands.

Fish stock reduction

Many failures of biomanipulation measures in peaty lakes are due to insufficient fish removal (Van Der Vlugt et al., 1992; Van Donk et al., 1994; Meijer et al., 1999). One explanation for this failure can be the large amount of canals, ditches and banks where fish can hide. Young cyprinids concentrate in small waters during winter and can escape netting (Meijer et al., 1999; Klinge et al., 2002). Therefore lake managers often suppose that sufficient fish removal is impossible in peaty lakes. On the other hand, when one knows where fish is hiding and how it migrates, it should be possible to catch sufficient amounts of fish to make biomanipulation work.

According to Meijer et al. (1999) fish stock reduction should be at least $75 \%$ of the cyprinids. This reduction percentage does not, however, take the original stock into account, nor the stock to be achieved (Gulati \& Van Donk, 2002). In the Netherlands a more absolute threshold to be reached is considered to be $<25 \mathrm{~kg} \mathrm{ha}^{-1}$ benthivorous fish and $<15 \mathrm{~kg} \mathrm{ha}^{-1}$ planktivorous fish (Meijer et al., 1998). Other thresholds mentioned in literature are $<50 \mathrm{~kg} \mathrm{ha}^{-1}$ planktivore fish (Gulati \& Van Donk, 2002), and 10-40 kg ha (Moss et al., 1996).
Recruitment of young fish can lead to a rapid recolonisation of the lake (Meijer et al., 1994, 1995; Gulati \& Van Donk, 2002), and fish removal may need to be repeated several times.

In this study we want to demonstrate that it is possible to reduce the fish stock in an 85 ha peaty lake sufficiently to switch the lake from a turbid to a clear state, and keep it that low the years after.

\section{Zooplankton grazing}

Zooplankton grazing, mainly by large bodied cladocerans such as Daphnia, is considered a key factor in the clearing of a lake after biomanipulation (Perrow et al., 1997; Meijer et al., 1999; Scheffer, 2001). Generally, large bodied cladocerans are not abundant in eutrophic peaty lakes. This may be because of high predation pressure by fish (Gulati et al., 1992; Van Donk et al., 1994), or unsuitability of the phytoplankton dominated by filamentous cyanobacteria (Blindow et al., 2000; DeMott et al., 2001a, b). The latter could be one reason why Daphnia does not develop in peaty lakes after biomanipulation (Van Donk et al., 1990; Lammens et al., 1992).

In this paper we will test the hypothesis that cladocerans will not develop after fish removal in a peaty lake.

Resuspension by wind and fish

In shallow lakes, turbidity or light attenuation is caused, generally, by phytoplankton, suspended detritus and dissolved coloured organic matter (Scheffer, 2001). The major sources of suspended detritus in a peaty lake are phytoplankton decomposition and resuspension of sediment (Gons et al., 1992). Major causes of resuspension are wind (Gons et al., 1986, 1991, 1992), and benthivorous fish (Meijer et al., 1990). Benthivorous fish, however, have not received adequate attention in studies of lake restoration (Gulati \& Van Donk, 2002).

Unsuccessful lake biomanipulation is often explained by wind induced resuspension (Van Donk et al., 1990; Van Der Vlugt et al., 1992), and biomanipulation in peaty lakes, with their loose bottom sediments, might not work due to 
wind resuspension (Van Liere \& Gulati, 1992; Van Liere \& Janse, 1992; Scheffer, 2001; Gulati \& Van Donk, 2002). In none of these studies, however, the role of wind resuspension and its interaction with fish stock removal was quantified. In general, resuspension by wind is estimated from windspeed, wind fetch, lake depth and sediment type (Meijer et al., 1999; Scheffer, 2001). Gons et al (1986, 1991) and Scheffer (2001) showed that it is surprisingly difficult to estimate wind resuspension, leading to a reliance on empirical relationships between turbidity, suspended matter and windspeed (Gons et al., 1991; Scheffer, 2001).

In this study we want to quantify both wind and fish induced resuspension in peaty lakes. We hypothesise that resuspension by wind and fish are major factors causing turbidity.

\section{Materials and methods}

\section{Study area}

Lake Terra Nova is an 85 ha shallow (0.5-2 m) peaty lake. At the west-side of lake lies a series of banks in a west-east direction. The eastern side of the lake is open water. The fetch depends largely on the wind angle and can be up to $0.75 \mathrm{~km}$. A map of the area is shown in van de Haterd and Ter Heerdt (2007).

As a consequence of eutrophication, algal blooms started in 1988. Turbidity increased from $1.2-1.9$ to $0.3-0.4 \mathrm{~m}$ Secchi-depth. The lake lost its varied, mesotrophic, macrophyte vegetation completely (see van de Haterd and Ter Heerdt, 2007). Part of Lake Terra Nova is covered by Nymphaea alba L. and Nuphar lutea (L.) Sm. Phytoplankton is dominated by filamentous cyanobacteria species that originally have been termed "Oscillatoria limnetica-like". This is a group of several related species, co-occurring in the lake, which belong to the Limnothrix/Pseudanabaena group, and Prochlorothrix hollandica (Zwart et al., 2005). Zooplankton is dominated by copepods, rotifers and Bosmina spp.

Total phosphorus concentration (TP) in 20012003 was $0.071 \pm 0.004 \mathrm{mg} \mathrm{l}^{-1} \quad($ Mean $\pm \mathrm{SE}$, $n=31)$. The fish population is typical for a eutrophicated peaty lake. Based on size and feeding habit we estimate that in 2000 there was $134 \mathrm{~kg} \mathrm{ha}^{-1}$ benthivorous fish (mainly bream, A. brama) and $80 \mathrm{~kg} \mathrm{ha}^{-1}$ planktivorous fish (mainly roach, $R$. rutilus) in the lake.

Lake Loenderveen is a 230 ha shallow peaty lake without banks and cuts. The fetch lies between $1.25 \mathrm{~km}$ and $2.0 \mathrm{~km}$. Data from this lake were used to test the effect of wind on turbidity.

Fish stock reduction

Fish was removed in October 2003-June 2004 and September 2004-June 2005. This time of the year was chosen because it is before spawning (Moss et al., 1996), before a spring increase in cladocerans (Perrow et al., 1997), and during the migration period of small cyprinids (Meijer et al., 1999; Klinge et al., 2002). From mid-September onwards, many fyke nets were placed in the canals to detect migration routes. Ditches were electrofished to remove winter concentrations of small fish. Open water was fished with $375 \mathrm{~m}$ seine nets during winter. Cuts were fished with $1,000 \mathrm{~m}$ gill nets, mesh 120-140 mm.

All larger fish were counted, weighted, and their length measured. Representative subsamples of smaller fish were measured. Weights are given in $\mathrm{kg} \mathrm{ha}^{-1}$ fresh weight. A Capture Mark Recapture method was used to estimate fish stock development during biomanipulation (Klinge et al., 2002).

\section{Light under water}

Vertical attenuation coefficient $\left(K_{\mathrm{d}}\right)$ was measured as $K_{\mathrm{d}}=\left(\ln \left(I_{0} / I_{Z}\right)\right) / Z$ where $I_{0}$ and $I_{Z}$ are the intensities of Photosynthetically Active Radiation (PAR) just under the water surface and at depth $z$ (Scheffer, 2001). PAR was measured with two LI-192SA underwater quantum sensors, mounted in a frame, $0.5 \mathrm{~m}$ apart. Measurements were taken every second during $30 \mathrm{~s}$ and averaged, using a LI-1400 data logger. Average $K_{\mathrm{d}}$ was measured over a 3 - to 10 -min period. 
Hydrochemical and biological data

Two sites were sampled, one open-water site (since 2001) and one Nymphaea site (since 2003). Each site was $50 \times 50 \mathrm{~m}^{2}$. Fortnightly to monthly samples were taken.

Water samples were taken with a tube which contained one (at $0.5 \mathrm{~m}$ water depth) to two litre water (at $>1 \mathrm{~m}$ water depth). At least 20 subsamples were taken and combined in a tub, until a volume of $30-401$ was gathered. From this volume samples were drawn for analysis. Per zooplankton sample 201 was used.

Chlorophyll $a$ and phaeopigment were measured after extraction in hot ethanol. Phytoplankton and zooplankton numbers were measured microscopically (minimal 200 individuals). Image analysis (Leica QWin v.3) was used to measure the body size dimensions for calculating zooplankton biovolume.

Suspended matter dry weight was measured by filtering up to 31 of water over a weighted $1.5 \mu$ filter. Phytoplankton dry weight concentration was estimated as $46 * \mathrm{CHL}$ (under light limitation, turbid water, $K_{\mathrm{d}} \geq 2 \mathrm{~m}^{-1}$ ) or $70^{*} \mathrm{CHL}$ (less light limitation, clear water, $K_{\mathrm{d}}<2 \mathrm{~m}^{-1}$ ) adapted from Gons et al. (1992) and Scheffer (2001). Suspended detritus dry weight was estimated as suspended matter minus phytoplankton dry weight.

Means are given as mean \pm SE. Data between 1st January and 15th April 2004, when fish stock was rapidly decreasing, were left out of statistical analysis.

Wind and fish induced resuspension

The contribution of wind and fish to the amount of suspended matter and turbidity was estimated from their empirical relationship. Though this relationship should be roughly sigmoidal, a linear model is sufficient if concentrations of suspended matter stay below saturation level (Gons et al., 1991; Scheffer, 2001; Scheffer et al., 2003).

Wind data between January 2001 and May 2005 were measured at Schiphol Amsterdam Airport, at a height of $10 \mathrm{~m}$. Schiphol is located in a open landscape, comparable with the study area at a distance of $25 \mathrm{~km}$.

\section{Results}

Fish stock reduction

We found several locations were fish concentrated and a few migration routes. This eased removal of most of the small fish with fykes and electrofishery (Table 1). Large fishes were mostly caught in open water with seine nets and in the cuts with gill nets (Table 1). Our goal of $<25 \mathrm{~kg} \mathrm{ha}^{-1}$ benthivorous fish and $<15 \mathrm{~kg} \mathrm{ha}^{-1}$ planktivorous fish was reached both in 2004 and 2005 (Table 2).

The recruitment in 2004 of perch (Perca fluviatilis L.) was $22.2 \mathrm{~kg} \mathrm{ha}^{-1}$, of roach it was $14.1 \mathrm{~kg} \mathrm{ha}^{-1}$. Hardly any young of the year bream were found.

\section{Clearing of the lake}

The clear water state reestablished in 2004 between April 14 and May 10 (Fig. 1). The mean attenuation coefficient after fish removal dropped from $3.10 \pm 0.12 \mathrm{~m}^{-1}$ to $1.58 \pm 0.09 \mathrm{~m}^{-1}$ (open-water site) and from $3.16 \pm 0.18 \mathrm{~m}^{-1}$ to $1.49 \pm 0.07 \mathrm{~m}^{-1}$ (Nymphaea site). This decrease was highly significant (Table 3 ). Lake bottom was visible all over the lake after fish removal.

Table 1 Catch per fishery method in Lake Terra Nova, winter 2003-2004 $\left(\mathrm{kg} \mathrm{ha}^{-1}\right)$

\begin{tabular}{lcc}
\hline & Fish $<25 \mathrm{~cm}$ & Fish $>25 \mathrm{~cm}$ \\
\hline Fykes & 140.3 & 28.2 \\
Electro fishery & 14.5 & 0.6 \\
Seine nets & 0.3 & 27.6 \\
Gill nets & 0.0 & 51.0 \\
Total & 155.1 & 107.3 \\
\hline
\end{tabular}

Table 2 Lake Terra Nova fish stock per year in $\mathrm{kg} \mathrm{ha}^{-1}$, based on Capture Mark Recapture method (*estimation based on catch)

\begin{tabular}{lrrl}
\hline & 2003 & 2004 & 2005 \\
\hline A. brama benthivorous & 119.5 & 8.7 & 9.3 \\
R. rutilus planktivorous & 41.6 & 1.3 & 4.1 \\
P. fluvialilis planktivorous & 6.8 & 0.4 & Low* \\
Tinca tinca L. & 32.1 & 11.9 & $10^{*}$ \\
Esox lucius L. & 28 & 22.7 & $20^{*}$ \\
Others & 15.8 & 2.8 & Low* \\
Total & 243.8 & 47.8 & - \\
\hline
\end{tabular}



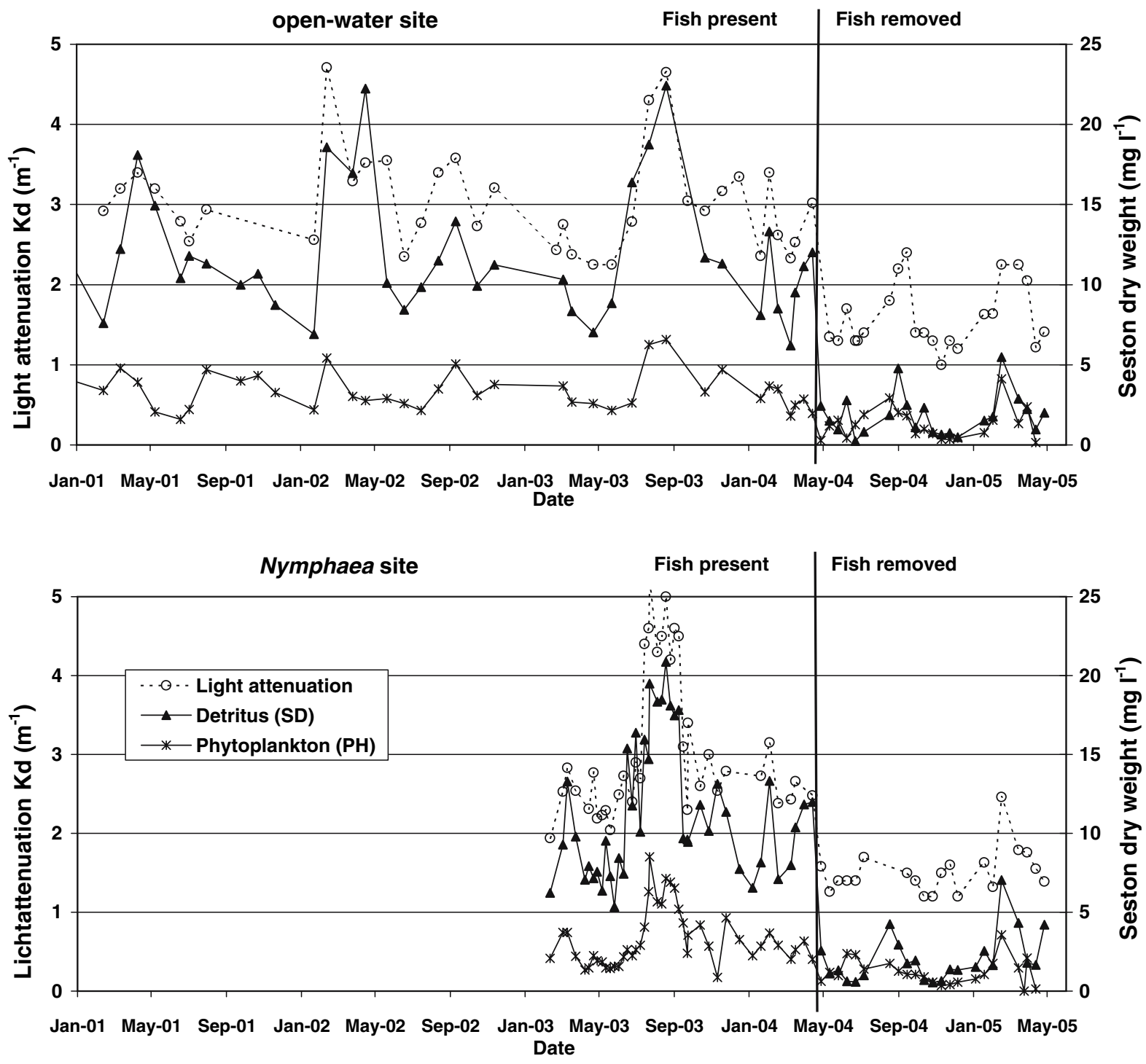

Fig. 1 Light attenuation $K_{\mathrm{d}}\left(\mathrm{m}^{-1}\right)$, phytoplankton biomass $\left(\mathrm{mg} \mathrm{l}^{-1}\right)$ and suspended detritus concentration $\left(\mathrm{mg}^{-1}\right)$ before and after fish removal in two stations in Lake Terra Nova in the period January 2001-May 2005

The lake transparency increased suddenly, not gradually. Between April 14 and May 10, the concentration of phytoplankton $(\mathrm{PH})$ and suspended detritus (SD) dropped sharply (Fig. 1). The difference in mean $\mathrm{PH}$ and SD before and after fish removal (Table 3) was highly significant.

The submerged vegetation cover increased from $0 \%$ to $30 \%$. The vegetation was characterised by Ceratophyllum demersum L., Najas marina L., Nitella mucronata A. Braun, Elodea nuttallii Planch., Potamogeton obtusifolius L., Utricularia vulgaris L., P. crispus L., Lemna trisulca L., P. lucens L. and Chara globularis Thuillier. (in order of decreasing cover, van de Haterd \& Ter Heerdt, 2007).

Zooplankton grazing

Before fish removal copepods and rotifers dominated zooplankton (Fig. 2). Cladoceran biovolume increased significantly after fish removal 
Table 3 Effects of fish removal on light, suspended detritus, plankton and phosphorus

\begin{tabular}{llccc}
\hline Parameter & Site & $\begin{array}{l}\text { Statistics before } \\
(\text { mean } \pm \mathrm{SE}, n)\end{array}$ & $\begin{array}{l}\text { Statistics after } \\
(\mathrm{mean} \pm \mathrm{SE}, n)\end{array}$ & $\begin{array}{l}\text { Comparison of } \\
\text { means }(t \text {-test })\end{array}$ \\
\hline Light attenuation, $K_{\mathrm{d}}\left(\mathrm{m}^{-1}\right)$ & Open water & $3.10 \pm 0.12,30$ & $1.58 \pm 0.09,22$ & $t=9.86, P<0.0001$ \\
& Nymphaea & $3.16 \pm 0.18,31$ & $1.49 \pm 0.07,21$ & $\begin{array}{l}t=7.48, P<0.0001 \\
t=11.10, P<0.0001\end{array}$ \\
Detritus, SD $\left(\mathrm{mg} \mathrm{l}^{-1}\right)$ & Open water & $12.55 \pm 0.79,31$ & $1.85 \pm 0.28,22$ & $t=9.56, P<0.0001$ \\
& Nymphaea & $11.84 \pm 0.77,34$ & $2.09 \pm 0.34,22$ & $t=6.84, P<0.0001$ \\
Phytoplankton, $\mathrm{PH}\left(\mathrm{mg} \mathrm{l}^{-1}\right)$ & Open water & $3.57 \pm 0.23,31$ & $1.29 \pm 0.22,21$ & $t=4.99, P<0.0001$ \\
& Nymphaea & $3.46 \pm 0.34,34$ & $1.22 \pm 1.22,22$ & $t=2.78, P=0.008$ \\
Cyanobacteria $\left(n^{-1}\right) \times 1,000$ & Open water & $174.9 \pm 71.0,18$ & $0.63 \pm 0.30,23$ & $t=4.29, P<0.0001$ \\
& Nymphaea & $209.4 \pm 38.8,35$ & $0.48 \pm 0.26,23$ & $t=3.75, P=0.001$ \\
Cladocerans $\left(\mathrm{mg} \mathrm{l}^{-1}\right)$ & Open water & $0.06 \pm 0.00,5$ & $4.84 \pm 1.28,24$ & $t=2.30, P=0.025$ \\
& Nymphaea & $1.21 \pm 0.21,35$ & $2.79 \pm 0.76,25$ & $t=0.47, P=0.642$ \\
Total phosphorus $\left(\mathrm{mg} \mathrm{l}^{-1}\right)$ & Open water & $0.071 \pm 0.004,31$ & $0.079 \pm 0.020,24$ & $t=0.47,25$ \\
& Nymphaea & $0.068 \pm 0.005,35$ & $0.073 \pm 0.019,22$ & $t=0.36, P=0.718$ \\
\hline
\end{tabular}

(Table 3) and cladocerans became dominant, though fluctuations were large (Fig. 2). In April, when the water cleared, Bosmina became abundant shortly, during the following months Daphnia dominated zooplankton (Fig. 2).

Before fish removal the phytoplankton consisted mainly of filamentous cyanobacteria (Fig. 2). When the lake cleared, phytoplankton biomass, suspended detritus (Fig. 1) and the number of cells of filamentous cyanobacteria dropped significantly (Fig. 2) and stayed significantly lower (Table 3 ). These decreases coincided with the short-lived peak of Bosmina (Fig. 2).

Resuspension by wind and fish

Light attenuation was significantly correlated with the concentration of phytoplankton $(\mathrm{PH})$ and suspended detritus (SD) (Table 4). These two parameters explained about $80 \%$ of the variation in light attenuation.

When the regression formulas (Table 4) are applied on the mean PH and SD (Table 3), the percentage contribution to light attenuation by constant, PH and SD can be estimated. Before fish removal, phytoplankton and suspended detritus contributed largely to turbidity (Table 5). After fish removal their combined contribution dropped to less than $35 \%$. Light attenuation after fish removal is mainly explained by the constant.

No significant correlation (linear regression) was found between mean windspeed during the day before the sampling date and light attenuation in either lake (Fig. 3). After fish removal in Terra Nova still no correlation was found (Fig. 3). The concentrations of suspended matter and suspended detritus also were not correlated with mean windspeed during the day before sampling (linear regression).

The concentration of fine-sized detritus was significantly correlated (linear regression) with the concentration of phytoplankton (Fig. 4). Before fish removal there was a significant constant of 5.5-6.39 $\mathrm{mg} \mathrm{l}^{-1}$ detritus. After fish removal there was no significant constant (Fig. 4).

Phosphorus levels

Total phosphorus level did not change significantly after fish removal (Table 3). However, a remarkable peak of $0.45-0.50 \mathrm{mg} \mathrm{P} \mathrm{l}^{-1}$ was recorded in 2004 between April 27 and May 10, during the sudden clearing of the lake. Orthophospate levels on these dates $(0.01$ and $0.07 \mathrm{mg}$ $\mathrm{P}^{-1}$, respectively) were only slightly higher than the usual $<0.01 \mathrm{mg} \mathrm{P}^{-1}$.

\section{Discussion}

Fish stock reduction

Fish stock can be reduced in peaty lakes with many cuts and banks when there is sufficient 

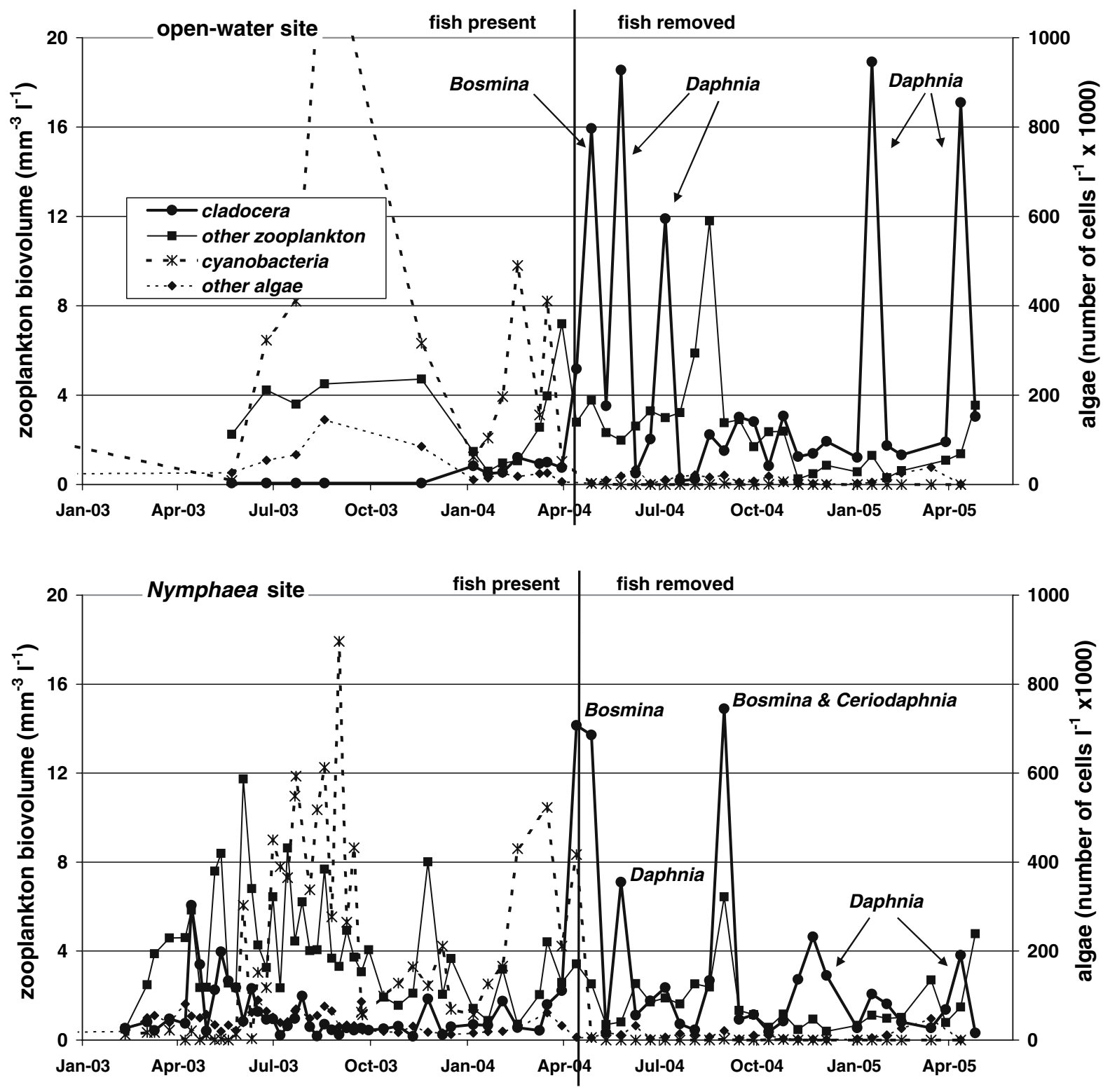

Fig. 2 Changes in zooplankton (biovolume, left axis) and in cyanobacteria (number of cells, right axis), before and after fish removal in Lake Terra Nova

knowledge of fish behaviour and habits. Different groups of fish and different areas require a variety of fishing methods. A stock of $<25 \mathrm{~kg} \mathrm{ha}^{-1}$ benthivorous fish and $<15 \mathrm{~kg} \mathrm{ha}^{-1}$ planktivorous fish can be reached and is sufficiently low to let a peaty lake return to a clear state. Even when the fish stock is very low, however, recruitment can be strong and the fish stock can grow above the threshold within 1 year. Meijer et al. (1994) also conclude that recruitment of planktivorous cyprinids in productive lakes can be strong. The large amount of cladocerans after the clearing of the lake provides a perfect food source. Until the cover with submerged macrophytes is large enough to compete effectively with phytoplankton (Blindow et al., 2000; Gulati \& Van Donk, 2002), high amounts of cladocerans are needed to maintain clear water (Meijer et al., 1994). There- 

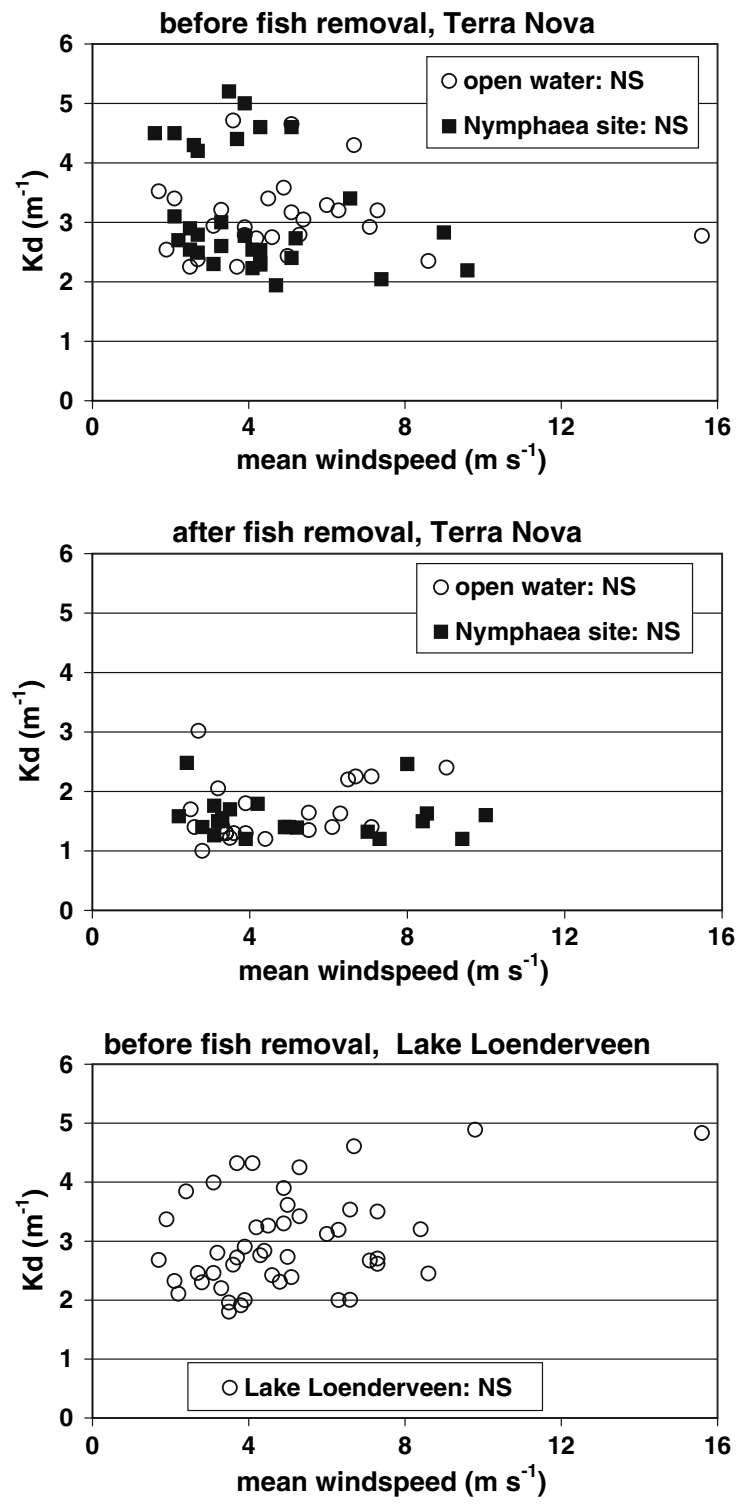

Fig. 3 Effect of mean wind speed $\left(\mathrm{m} \mathrm{s}^{-1}\right)$ the day before sampling on light attenuation $\mathrm{K}_{\mathrm{d}}\left(\mathrm{m}^{-1}\right)$ between January 2001 and May 2005 in Lake Terra Nova and Lake Loenderveen. Linear regression never was significant
Table 4 Linear regression analysis effect of phytoplankton $\left[\mathrm{PH}, \mathrm{mg} \mathrm{l}^{-1}\right]$ and detritus ( $\mathrm{SD}, \mathrm{mg} \mathrm{l}^{-1}$ ) on light attenuation $K_{\mathrm{d}}\left(\mathrm{m}^{-1}\right) K_{\mathrm{d}}=$ constant $+B_{1}[\mathrm{PH}]+B_{2}[\mathrm{SD}]$

\begin{tabular}{lllll}
\hline & Constant & $B_{1}$ & $B_{2}$ & $R^{2}$ \\
& $(\mathrm{PH})$ & $(\mathrm{SD})$ & \\
\hline $\begin{array}{c}\text { Open-water site, before } \\
\text { fish removal }\end{array}$ & $1.28^{* * *}$ & $0.25^{* * *}$ & $0.08^{* * *}$ & 0.80 \\
$\begin{array}{c}\text { Nymphaea } \text { site, before } \\
\text { fish removal }\end{array}$ & $1.00^{* * *}$ & $0.27^{* * *}$ & $0.10^{* * *}$ & 0.79 \\
$\begin{array}{c}\text { Open-water site, after fish } \\
\text { removal }\end{array}$ & $1.14^{* * *}$ & $0.15^{* *}$ & $0.14^{* * *}$ & 0.88 \\
$\begin{array}{c}\text { Nymphaea } \text { site, after fish } \\
\text { removal }\end{array}$ & $1.21^{* * *}$ & $0.09^{\mathrm{NS}}$ & $0.10^{* * *}$ & 0.81 \\
\hline & & & & \\
\hline
\end{tabular}

$* P<0.05 ; * * * P<0.001 ;$ NS, not Significant

fore fisheries have to be continued for several years to keep planktivorous fish stock low. We presume that after a few years the macrophytes can provide sufficient cover for zooplankton and the fishery effort can be reduced.

In temperate peaty lakes the winter period is the most suitable period for fish removal as the fish concentrates during this time. Throughout the summer the fish are more homogeneously distributed (Klinge et al., 2002). For the same reason, however, the winter season is unsuitable for accurate fish stock monitoring (Klinge et al., 2002). Fish stock sampling with trawl or seine nets is difficult in peaty lakes due to the large area of cuts, ditches and banks. Capture Mark Recapture methods before and during the fisheries will give a reliable insight in the achievements.

Care should be taken not to use fish stock data of more than 1 or 2 years old to determine the amounts of fish to be caught, as annual differentiation in growth, recruitment or death might change population sizes rapidly.

Table 5 Percentage contribution to light attenuation of constant, phytoplankton and suspended detritus. Linear regression analysis

\begin{tabular}{llll}
\hline & Constant & Phytoplankton & Detritus \\
\hline Open-water site, before fish removal & 43 & 28 & 30 \\
Nymphaea site, before fish removal & 34 & 30 & 37 \\
Open-water site, after fish removal & 66 & 12 & 22 \\
Nymphaea site, after fish removal & 74 & 8 & 18 \\
\hline
\end{tabular}



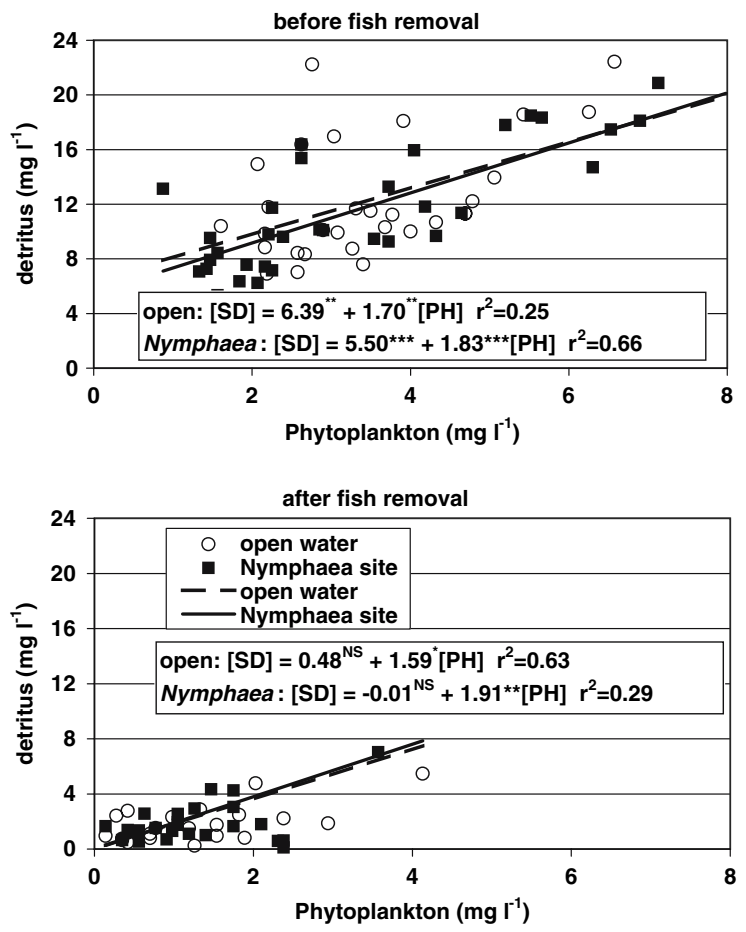

Fig. 4 Effect of phytoplankton concentration (PH) on suspended detritus concentration (SD) in Lake Terra Nova. Significant linear regression equations are shown also

\section{Zooplankton grazing}

In contrast with our expectations cladocerans, such as Bosmina, Daphnia and Ceriodaphnia became abundant after fish removal. The sudden appearance of large numbers of Bosmina coincided with the sudden decrease of cyanobacteria and detritus between April 14 and May 10. We cannot imagine any other explanation for this decrease than that Bosmina was able to consume filamentous cyanobacteria and maybe detritus as well. We found some indications in literature that support this thought. In Lake Vogelenzang in The Netherlands the cyanobacteria disappeared after a high peak of Bosmina also (Van Der Vlugt et al., 1992). Bosmina species are well adapted to food dominated by cyanobacteria, can be the most important grazers in a peaty lake and often appear in early spring (Gulati et al., 1992). On the other hand Meijer et al. (1999) consider potential grazing of Bosmina negligible compared to that of Daphnia.
After an initial 'bloom' Bosmina decreases again in Lake Terra Nova. Daphnia takes over when the amount of cyanobacteria is negligible. The remaining phytoplankton will be of good quality for cladocerans (DeMott et al., 2001a, b). This corresponds to the observation of Kurmayer (2001) that larger cladocerans have a competitive advantage over smaller cladocerans in exploiting limited food resources.

DeMelo et al. (1990) debated the whole concept of top-down control after biomanipulation. Our study shows that top-down control by cladocerans likely will be one of the factors determining whether a lake is turbid or clear.

Resuspension by wind and fish

We conclude that resuspension by wind is not a major factor determining detritus concentration and light attenuation, as we did not find any correlation between windspeed and suspended detritus in the 85 ha Lake Terra Nova, nor in the 230 ha Lake Loenderveen. In our shallow peaty lakes, though the sediment is very loose, resuspension by wind will not prevent biomanipulation being successful.

This is not as unexpected as it appears. Gons et al. (1986) measured a strong resuspension when windspeed exceeded $7 \mathrm{~m} \mathrm{~s}^{-1}$ in Lake Loosdrecht (980 ha). One day later, however, concentration of suspended matter returned closely to its previous level. Short-term variations in turbidity, between 16 and 30 NTU, followed windspeed and an averaged hourly windspeed of $5 \mathrm{~m} \mathrm{~s}^{-1}$ was the threshold for wind resuspension in Lake Loosdrecht (Gons et al., 1991). The lakes we studied are much smaller and therefore the threshold will be larger and the wind induced fluctuations in turbidity less frequent and smaller.

We conclude that the amount of detritus resuspended by fish on average was 5.50$6.39 \mathrm{mg} \mathrm{l}^{-1}$, which is about $50 \%$ of the mean detritus concentration, as the constant in our linear regression equation describing the relation between detritus and phytoplankton became not significantly different from zero after fish removal (Fig. 4). Gons et al. (1991) postulate from their regression analysis that resuspension by fish was quantitatively unimportant. As the constant of 
about 16 FTU in their equation remained unexplained, however, the activity of benthic fish still might be a major cause of resuspension.

Sinking rates of fine sized detritus can be very low. Gons et al. (1992) concluded that about 14\% of the fine sized detritus might be present 1 year later. In our study, however, the concentration of suspended detritus showed rapid changes, following phytoplankton concentration. This implies not only that significant amounts of detritus can be 'produced' rapidly, but also that detritus disappears rapidly from the water column. During the clearing of the lake, detritus concentration dropped to near zero within a few weeks. This suggests that sinking rates of detritus are higher than expected. One other explanation might be that Bosmina consumed detritus as well as algae.

In several other studies, resuspension by wind, even in large lakes, did not prevent lakes to become clear after biomanipulation in the Netherlands (Meijer et al., 1999; Scheffer, 2001). Benthivorous fish can facilitate wind resuspension largely by reducing the erosion resistance of the sediment and fish removal thus can lead to a decrease of wind resuspension (Scheffer et al., 2003). Wind resuspension will play a role in a lake ecosystem, however, as it might stir up the bottom temporarily and sinking sediment can cover plants. But we conclude that it will not prevent biomanipulation from being successful.

As expected, most of the variation in light attenuation can be explained by variation in phytoplankton and suspended detritus (Gons et al., 1992; Scheffer, 2001). Like in Lake Loosdrecht (Gons et al., 1992), in Lake Terra Nova the concentrations of detritus and phytoplankton are coupled. Apparently phytoplankton decomposition will be an important source of detritus.

The constant of 1.00-1.28 found in the regression between light attenuation and detritus and phytoplankton (Table 3) might be caused by the presence of Coloured Dissolved Organic Matter (CDOM). Concentrations of CDOM can be quite high in peaty lakes (Rijkeboer et al., 1997). In Lake Terra Nova CDOM concentration is around $13 \mathrm{mg} \mathrm{l}^{-1}$. The major source of CDOM could be the sediment; the concentration in peat pore water in neighbouring Lake Loenderveen was 30$66 \mathrm{mg} \mathrm{l}^{-1}$. When the bottom is less disturbed by fish and wind the CDOM concentration in the lake might drop.

Lake productivity

With a TP concentration in 2001-2003 of $0.071 \pm 0.004 \mathrm{mg} \mathrm{P} \mathrm{l}^{-1}$, the lake is not very eutrophic. TP-levels did not change significantly after fish removal. According to Jeppesen et al. (1990b) a minimum summer concentration below $0.08-0.15 \mathrm{mg} \mathrm{P}^{-1}$ is needed to establish a stable clear water state. This threshold was reached in Lake Terra Nova. The peaty lakes in the evaluation of Meijer et al. (1999) had TP concentrations between 0.1 and $0.44 \mathrm{mg} \mathrm{P} \mathrm{l}{ }^{-1}$, which might explain why biomanipulation in peaty lakes failed.

The peak values of TP; $0.45-0.50 \mathrm{mg} \mathrm{P}^{-1}$ measured in 2004 between April 27/May 10, were the highest values measured ever in Lake Terra Nova. Since 1977 the highest level recorded was $0.15 \mathrm{mg} \mathrm{P} \mathrm{l}^{-1}$. As orthophosphate levels were not raised much, we conclude that this P-load was present in suspended matter: zooplankton, phytoplankton or detritus. The source of this sudden increase remains unknown, but it coincided with the decrease of phytoplankton and detritus and the short term increase of Bosmina. We assume that there is a relation between the clearing of the lake and the peak TP-values. As we cannot offer any reliable explanation for this phenomenon, we will not speculate about it.

\section{Conclusions}

With sufficient knowledge of lake morphology, fish stock, fish behaviour, and a variety of fishing methods the fish stock in a peaty lake can be reduced to very low levels. Continuation of fisheries to remove young of the year of planktivorous species is needed for several years until macrophytes provide sufficient cover to zooplankton.

The main goal of this biomanipulation experiment, clear water and increased submerged plant cove was reached.

Most likely Bosmina is able to reduce filamentous cyanobacteria and detritus, while Daphnia is able to keep phytoplankton levels low. 
In our case, resuspension by wind is not a major factor determining light attenuation and detritus concentration and did not prevent biomanipulation from being successful. On average, resuspension of detritus by fish explained about half of the amount of detritus, the other half can be explained by phytoplankton.

Acknowledgements The biomanipulation of Lake Terra Nova was funded by the Dutch Ministry of Agriculture, Nature and Food Quality. We want to thank our colleagues from The Water Laboratory for the analysis of the numerous samples. Dr. K. Irvine helped us to improve the English text.

\section{References}

Blindow, I., A. Hargeby, B. M. A. Wagner \& G. Andersson, 2000. How important is the crustacean plankton for the maintenance of water clarity in shallow lakes with abundant submerged vegetation? Freshwater Biology 44: 185-197.

DeMelo, R., R. France \& D. J. McQueen, 1990. Biomanipulation: Hit or Myth? Limnology and Oceanography 37: 192-207.

DeMott, W. R., R. D. Gulati \& E. Van Donk, 2001a. Effects of dietary phosphorus deficiency on the abundance, phosphorus balance, and growth of Daphnia cucullata in three hypertrophic Dutch lakes. Limnology and Oceanography 8: 1871-1880.

DeMott, W. R., R. D. Gulati \& E. Van Donk, 2001b. Daphnia food limitation in three hypereutrophic Dutch lakes: evidence for exclusion of large bodied species by interfering filaments of Cyanobacteria. Limnology and Oceanography 46: 2054-2060.

Gons, H. J., T. Burger-Wiersma, J. H. Otten \& M. Rijkeboer, 1992. Coupling of phytoplankton and detritus in a shallow, eutrophic lake (Lake Loosdrecht, The Netherlands). Hydrobiologia 233: 51-59.

Gons, H. J., J. H. Otten \& M. Rijkeboer, 1991. The significance of wind resuspension for the predominance of filamentous cyanobacteria in a shallow, eutrophic lake. Memorie Dell'Instituto Italiano De Idrobiologia Dott. Marco De Marchi 48: 233-249.

Gons, H. J., R. Veeningen \& R. Van Keulen, 1986. Effects of wind on a shallow lake ecosystem: resuspension of particles in the Loosdrecht lakes. Hydrobiological Bulletin 20: 109-120.

Gulati, R. D., A. L. Ooms-Wilms, O. F. R. Van Tongeren, G. Postema \& K. Siewertsen, 1992. The dynamics and role of limnic zooplankton in Loosdrecht Lakes (The Netherlands). Hydrobiologia 233: 69-86.

Gulati, R. D. \& E. Van Donk, 2002. Lakes in the Netherlands, their origin, eutrophication and restoration: state-of-the-art review. Hydrobiologia 478: 73-106.

Jeppesen, E., J. P. Jensen, P. Kristensen, M. Sondergaard, E. Mortensen, O. Sortkjaer \& O. K. Olrik, 1990b. Fish manipulation as a lake restoration tool in shallow, eutrophic, temperate lakes 2: threshold levels, longterm stability and conclusions. Hydrobiologia 200/201: 219-227.

Jeppesen, E., J. P. Jensen, M. Sondergaard, T. Lauridsen, L. J. Pedersen \& L. Jensen, 1997. Top-down control in freshwater lakes: the role of nutrient state, submerged macrophytes and water depth. Hydrobiologia 342: 151-164.

Jeppesen, E., J. P. Jensen, M. Sondergaard, E. Mortensen, P. Kristensen, B. Rieman \& P. J. Jensen, 1990a. Fish manipulation as a lake restoration tool in shallow, eutrophic, temperate lakes 1: cross-analysis of three Danish case-studies. Hydrobiologia 200/201: 205-218.

Klinge, M., G. Hensens, A. Brennikmeijer \& L. Nagelkerke, 2002. Handboek visstandbemonstering, voorbereiding, bemonstering, beoordeling (Manual for Fish stock monitoring, in Dutch). STOWA, Utrecht.

Kurmayer, R., 2001. Competitive ability of Daphnia under dominance of non-toxic filamentous cyanobacteria. Hydrobiologia 442: 279-289.

Lammens, E. H. R. R., N. Boesewinkel-De Bruyn, H. Hoogveld \& E. Van Donk, 1992. P-load, phytoplankton, zooplankton and fish stock in Loosdrecht Lake and Tjeukemeer: confounding affects of predation and food availability. Hydrobiologia 233: 87-94.

Meijer, M. L., I. De Boois \& R. Portielje, 1998. Actief Biologisch Beheer: de meest effectieve maatregel? (Active Biological Management: the most effective measure? In Dutch) H2O, 23-26.

Meijer, M. L., I. De Boois, M. Scheffer, R. Portielje \& H. Hosper, 1999. Biomanipulation in shallow lakes in The Netherlands: an evaluation of 18 case studies. Hydrobiologia 409: 13-30.

Meijer, M. L., M. W. De Haan, A. W. Breukelaar \& H. Buitenveld, 1990. Is reduction of the benthivorous fish an important cause of high transparency following biomanipulation in shallow lakes? Hydrobiologia 200/ 201: 303-315.

Meijer, M. L., E. H. R. R. Lammens, A. J. P. Raat, J. G. P. KleinBreteler \& M. P. Grimm, 1995. Development of fish communities in lakes after biomanipulation. Netherlands Journal of Aquatic Ecology 29: 91-101.

Meijer, M. L., E. Jeppesen, E. Van Donk, B. Moss, M. Scheffer, E. H. R. R. Lammens, E. Van Nes, J. A. Van Berkum, G. J. De Jong, B. A. Faafeng \& J. P. Jensen, 1994. Long-term responses to fish-stock reduction in small shallow lakes - interpretation of 5-year results of 4 biomanipulation cases in The Netherlands and Denmark. Hydrobiologia 276: 457-466.

Moss, B., J. Madgwick \& G. Phillips, 1996. A Guide to the Restoration of Nutrient-enriched Shallow Lakes. The Broads Authority, Norwich.

Perrow, M. R., M. L. Meijer, P. Dawidowicz \& H. Coops, 1997. Biomanipulation in shallow lakes: state of the art. Hydrobiologia 342: 355-365.

Rijkeboer, M., A. G. Dekker \& H. Gons, 1997. Subsurface irradiance reflectance spectra of inland waters differing in morphology and hydrology. Aquatic Ecology 31: 313-323. 
Scheffer, M., 2001. Ecology of shallow lakes. Kluwer Academic Publishers, Dordrecht, Boston, London.

Scheffer, M., R. Portielje \& L. Zambrano, 2003. Fish faciliate wave resuspension of sediment. Limnology and Oceanography 48: 1920-1926.

van de Haterd, R. J. W. \& G. N. J. Ter Heerdt, 2007. Potential for the development of submerged macrophytes in eutrophicated shallow peaty lakes after restoration measures. Hydrobiologia 584: 277-290.

Van Der Vlugt, J. C., P. A. Walker, J. Van Der Does \& A. J. Raat, 1992. Fisheries management as an additional lake restoration measure: biomanipulation scaling-up problems. In van Liere, L. \& R. D. Gulati (eds), Restoration and Recovery of Shallow Eutrophic Lake Ecosystems in the Netherlands. Kluwer Academic Publishers, Dordrecht/Boston/London, 213-224.

Van Donk, E., M. P. Grimm, R. D. Gulati, P. G. M. Heuts, W. A. De Kloet \& L. Van Liere, 1990. First attempt to apply whole-lake foodweb manipulation on a large scale in The Netherlands. Hydrobiologia 200/201: 291-301.

Van Donk, E., M. P. Grimm, P. G. M. Heuts, G. Blom, K. Everards \& O. F. R. Van Tongeren, 1994. Use of mesocosms in a shallow eutrophic lake to study the effects of different restoration measures. Archiv für Hydrobiologie Beiheft 40: 283-294.

Van Liere, L. \& R. D. Gulati, 1992. Restoration and recovery of shallow eutrophic lake ecosystems in The Netherlands: epilogue. Hydrobiologia 233: 283-287.

Van Liere, L. \& J. H. Janse, 1992. Restoration and resilience to recovery of the Lake Loosdrecht ecosystem in relation to its phosphorus flow. Hydrobiologia 233: 95-104.

Zwart, G., M. P. Kamst-van Agterveld, I. Van der WerffStagerman, F. Hagen, H. Hoogveld \& H. J. Gons, 2005. Molecular characterization of cyanobacterial diversity in a shallow eutrophic lake. Environmental Microbiology 7: 365-377. 